\title{
DOMINICOS Y MORISCOS EN EL REINO DE VALENCIA
}

\author{
EMiLio CALLADO ESTELA \\ Universidad CEU-Cardenal Herrera. Valencia
}

Fecha de recepción: septiembre 2008

Fecha de aceptación: diciembre 2008

Desde su establecimiento en el levante peninsular de la mano del monarca Jaime I, la corona encomendó a la orden de frailes Predicadores la atención espiritual de las minorías religiosas ${ }^{1}$, impulsada a partir de 1248 por el dominico fray Andrés de Albalat, obispo a la sazón de la diócesis de Valencia² ${ }^{2}$ A la muerte de este prelado, acaecida tres décadas después, la continuidad en la predicación a judíos y musulmanes -especialmente a estos últimos- quedó garantizada por el padre Juan de Puigventós, escogido por el difunto fray Andrés entre las filas de santo Domingo para «predicar y corregir y instruyr a los nuevos convertidos del reyno»; elección episcopal ratificada en 1279 por un privilegio de Pedro I que ofreció al religioso hasta el último oficial real para colaborar en estas labores evangélicas. Por su parte, también las autoridades blanquinegras -reunidas en el posterior capítulo provincial de Estella-confiaron al padre Puigventós la enseñanza de la lengua de Mahoma, en la que andaba muy versado, poniéndole al frente del Studium Arabicum del principal establecimiento dominicano del reino, en la capital, para asignarle por alumnos a sus hermanos de hábito fray Pedro Terter, fray Martín de Sarrión, fray Juan Serrano, fray García de Arce y un tal fray Nadal, a fin de que «aprendiéndola pudiessen predicar a los moros y convertirlos». Como otros centros similares erigidos en Xàtiva, Barcelona, o Mallorca, el estudio valentino tendría encomendada la formación de aquellos frailes que, por vocación o mandato, debían dedicarse al diálogo con el islam, contando necesariamente con una

\footnotetext{
1. Diago, Francisco: Historia de la Provincia de Aragón de la orden de Predicadores, desde su origen y principio hasta el año de mil y seyscientos, Barcelona: Impressa por Sebastián de Cormellas en Sancta Catherina mártyr, 1599, ff. 160-161v.

2. TeIXIDOR, José: Episcopologio de Valencia (1092-1773), Valencia: Facultad de Teología San Vicente Ferrer, 1998, pp. 45-49.
} 
sólida preparación teológica que les capacitara para exponer la verdadera fe y defenderla de sus adversarios, en tierras de misión y donde quiera que la Iglesia precisase ${ }^{3}$.

Varias generaciones de religiosos pasaron por estas aulas del convento de Predicadores hasta su desaparición en el primer tercio del Cuatrocientos, fallecido sólo unos años antes su más ilustre morador, el padre Vicente Ferrer. El futuro santo, dominico prototípico en tantos aspectos, intentó a lo largo de su vida atraer a los sarracenos gracias al conocimiento de su doctrina - entresacada principalmente del Corán- y transmitirles un mensaje cristiano de salvación ${ }^{4}$. En su itinerario apostólico peninsular, llegó a viajar hasta Granada entre 1407 y 1408 -con el sobrenombre de Aben Balvallamado por el rey moro Mahomet IX .

Nada hace suponer que durante la centuria siguiente los hijos del patriarca de Caleruega cambiaran de estrategia respecto a los musulmanes, cuya conversión masiva, decretada para la Corona de Aragón en 1525, acabaría dando una nueva dimensión al problema con la aparición de los llamados moriscos. Frente a éstos, los frailes predicadores adoptaron en principio una postura conciliadora clara, muy próxima a la monarquía, que iría difuminándose con el transcurrir del tiempo, paralelamente a los reiterados fracasos de las políticas asimiladoras y las cuitas internas de la orden, que romperían la unidad de acción inicial. De todo ello tratan las presentes líneas, que parten de los datos proporcionados por los profesores B. Vincent y R. Benítez - en su excelente introducción a la edición facsimilar de la obra seiscentista de fray Jaime Bleda Corónica de los moros de España ${ }^{6}$ - para analizar el asunto con mayor detenimiento, en el caso concreto del reino de Valencia, sirviéndonos de la bibliografía dominicana clásica y más reciente, así como de distintas fuentes documentales blanquinegras desperdigadas por el Archivo Histórico de la Provincia de Aragón, el del Real Convento de Predicadores de Valencia y la Biblioteca Universitaria de esta misma ciudad ${ }^{7}$.

3. Cortabarria Beitia, Andrés: «Originalidad y significación de los Studia Linguarum de los dominicos españoles de los siglos XIII y XIV», Pensamiento: Revista de Investigación e Información Filosófica, Madrid, 1969, $\mathrm{n}^{\circ}$ 25, pp. 71-100; y «El estudio de las lenguas en la orden dominicana», Estudios Filosóficos, Valladolid, 1970, vol. XIX, pp. 79-127 y 359-392. También RoBLES, Laureano: «El Studium Arabicum del capítulo dominicano de Toledo de 1250. Antecedentes del Miramar de Ramón Llull», Estudios Lulianos, Palma de Mallorca, 1980, vol. XXIV, pp. 33-34.

4. Robles Sierra, Adolfo: «San Vicente Ferrer en el contexto del diálogo: las minorías religiosas», Escritos del Vedat, Torrent, 1996, vol. XXVI, pp. 150-155.

5. RANZANO, Pietro: Vita sancti Vincentii Ferrerii, Valencia, 1693, lib. II, cap. 4; y FAGES, Hubert.: Historia de san Vicente Ferrer, apóstol de Europa, Valencia: A. García, 1903, pp. 190 y ss. Sobre el tema véase, en cualquier caso, Garganta, José María, y ForCada Comins, Vicente: San Vicente Ferrer. Biografía y escritos, Madrid: La Editorial Católica, 1956, p. 158.

6. Vincent, Bernard, y Benítez SÁnchez-Blanco, Rafael: «Los dominicos y los moriscos», Corónica de los moros de España de fray Jaime Bleda (Ed. Facsimilar), Valencia: Universitat de València-Biblioteca Valenciana, 2001, p. 16.

7. Robles Sierra, Adolfo: «Manuscritos del Archivo del Real Convento de Predicadores de Valencia», Escritos del Vedat, Torrent, 1984, vol. XIV, pp. 349-372; ROBLES SIERRA, Adolfo, y ESPONERA CERDÁN, Alfonso: «Documentos sobre la expulsión de los moriscos del reino de Valencia en el actual archivo del real convento de Predicadores de Valencia», Anales Valentinos, Valencia, 1996, n 44, pp. 389-395; y 


\section{LAS PRIMERAS CAMPAÑAS DE EVANGELIZACIÓN}

Las circunstancias de precipitación y brutalidad con que se había impuesto el bautismo a los musulmanes en los territorios de la Corona de Aragón pronto hicieron necesarias campañas de evangelización, que promovidas por la corona y amparadas por la Santa Sede fueron numerosas desde $1526^{8}$. La orden de santo Domingo, según sus cronistas, «no pudo faltar a esta empresa, favoreciéndola muchíssimo»; ${ }^{9}$ una de las figuras más destacadas en este sentido sería la de fray Juan de Salamanca, predicador real que recorrió por aquellas fechas el territorio valenciano llevando la palabra de Dios a los moriscos ${ }^{10}$.

En 1539 la Provincia dominicana de Aragón daba otro paso adelante y respondía a la última llamada de Carlos I en aras de un nuevo empuje misional abordando el tema en el capítulo reunido en Calatayud, donde se acordó lo siguiente

«...attendentes ordinem nostrum ad propagandam precipue fidem esse institutum, et in hac Provincia plurimum periclitari apud noviter conversus, ordinamus, et ordinantes mandamus in virtute Dei et Sancta obedientia, reverendi patri frater Ioanni Mico, magistro priori conventus Sancti Onophrii, et frater Benedicto de Sancta Maria, praesentato, priori valentino, assumpta primum benedictione a reverendissimo archiepiscopo ac coepiscopis, quod discurrant per oppida et villas totius regni Valentiae, et praedicantes sincere evangelium Christi tempore, quod magis opportunum iudicaverint semel, vel plures in unoquoque anno, si expedierit. Idem, dicimus faciendum per reverendus pater frater Iacobum Ferran, magistrum et priorem Caesaraugustanum, et frater Thomam de Paredes, praedicatorem generalem et priorem de Gotor» ${ }^{11}$.

Cuatro predicadores oficiales, dos para el reino de Aragón, fray Tomás Paredes y fray Jaime Ferrán, y otros tantos para el de Valencia, fray Benito de Santa María y fray Juan Micó, tendrían a su cargo, pues, la labor evangelizadora encomendada por la Provincia conforme a la voluntad regia. Ninguno de ellos era desconocido en los ambientes blanquinegros. No el padre Paredes, desde luego, prior del aragonés conven-

Callado Estela, Emilio, y EsPonera Cerdán, Alfonso: «Aproximació històrica a l'arxiu i biblioteca del Reial Convent de Predicadors de València», y CABEZA SÁnCHEZ-AlboRnoz, Mari Cruz: «Els fons bibliogràfics del Reial Convent de Predicadors a la Universitat de València», ambos en Palau de la Saviesa. El convent de Predicadors de València i la Biblioteca Universitària, Valencia: Universitat de València, 2005, pp. 95-106 y 107-124, respectivamente.

8. Biblioteca Universitaria de Valencia (BUV): Ms. 933, TEIXIDOR, José: Necrologio de este real convento de Predicadores de Valencia. Devidas memorias a sus hijos nativos, con extensión en los más ilustres, recogidas de monumentos authénticos i seguros. Tomo II, pp. 293 y ss. Detalles dominicanos a un lado, el relato de los hechos ofrecido por fray José sigue muy de cerca las noticias proporcionadas a este mismo respecto por Escolano, Gaspar: Década primera de la Historia de Valencia (Ed. Facsimilar), Valencia: Universitat de València, 1972, vol. IV, cols. 1.743 y ss.

9. BUV: Ms. 801 (26), Tres grandes fenómenos ocurridos en Valencia en el año 1517, precursores de males que posteriormente ocurrieron, f. 578.

10. Vincent, Bernard, y Benítez SÁncheZ-Blanco, Rafael: Op. cit., p. 16.

11. Archivo Histórico de la Provincia Dominicana de Aragón (AHPDA): Ms. 4, Acta capituli provincialis. Calatayud MDXXXVIIII, sf. 
to reformado de Gotor, como tampoco el padre Ferrán, cuya elección resulta inevitable relacionar con sus orígenes musulmanes. Libio de cuna éste, había sido arrancado de Trípoli, todavía niño, por una expedición cristiana que lo condujo a Barcelona para recibir las aguas bautismales; allí vistió el hábito dominicano, graduándose en Teología para ocupar en breve el priorato del convento de Santa Catalina Mártir, en la misma Ciudad Condal, y más tarde el de Zaragoza, que dejaría con posterioridad para convertirse en Provincial ${ }^{12}$. Por su parte, la experiencia en el apostolado del padre Santa María, superior de Santo Domingo, en Valencia, también hacía de él un buen candidato para ocuparse de los moriscos ${ }^{13}$.

El protagonismo de esta campaña, sin embargo, iba a recaer en otro gran predicador, el padre Micó, prior del convento de San Onofre de Museros, tras haberlo sido antes de otros establecimientos religiosos de la orden y ocupado el cargo de Provincial como estandarte de la reforma dominicana ${ }^{14}$. Quien habría de convertirse en el más celoso misionero dominico de los nuevos convertidos hubo de esperar todavía un tiempo para entregarse a esta labor, por cuanto el fallecimiento de su superior, fray Tomás Guzmán, lo puso al frente de los destinos de la Provincia de Aragón hasta la reunión del capítulo de Barcelona, a comienzos de 1541. Liberado de sus obligaciones en la orden, fray Juan pudo desplazarse a Valencia en el mes de marzo. Allí se puso a disposición de los obispos don Antonio Ramírez de Haro, de Calahorra, y don Francisco de Navarra, de Ciudad Rodrigo, comisarios apostólicos para la evangelización morisca establecidos en la capital del Turia por orden del monarca ${ }^{15}$. Siguiendo sus instrucciones, el dominico predicó por diferentes lugares del reino una vez finalizada la Cuaresma, haciendo alarde de sus dotes homiléticas con «ingenio claro, memoria grande, lengua expedita, voz grave i sonora, rostro severo (y) muchas letras divinas». De las dificultades halladas en su labor mantuvo puntualmente informados a ambos comisarios. Uno de ellos, don Francisco, encomió en julio de 1541 los desvelos del religioso, agradeciéndole el celo con que

«...ha tomado esta empresa de querer sembrar la palabra de Dios a essa gente mal enseñada en lo que más le importa. Plegue a Nuestro Señor, por su infinita misericordia, se apiade de tantas ánimas que están cegadas i enlazadas por Sathán, i como fue servido por su immensa misericordia redemillas con su muerte i passión inestimable las quiera librar de la expurcíssima $i$ nefanda secta mahomética i quiera infundir tanta gracia en las palabras de vuestra merced $i$ de los que entienden en estas predicaciones que no caiga la simiente de la palabra de Dios sobre las piedras o entre las espinas o cerca del camino,

12. Diago, Francisco: Op. cit., ff. 99-100.

13. BUV: Ms. 933, TeIXIDOR, José: Necrologio de este real convento de Predicadores ..., tomo II, p. 614.

14. FUENTES, Celedonio: Escritores dominicos del reino de Valencia, Valencia: Imprenta F. Ángeles Pitarch, 1930, pp. 225-231; RoBLES, Laureano: «Ne pereant. 15 documentos relativos a fray Juan Micó, o.p. (1498-1555)», y «Juan Micó, o.p., autor del Rosarium sive psalterium Sanctissimi Nominis Jesu», ambos en Escritos del Vedat, Torrent, 1976, vol. VI, pp. 203-232, y 1981, vol. XI, pp. 339-360; y SoLER, Abel, y Terol, Vicent: El Palomar. On es troben la sèquia $i$ el camí, Ontinyent: Obra Social de la Caixa d'Estalvis d'Ontinyent, 1996, pp. 408-432.

15. Escolano, Gaspar: Op. cit., cols. 1.743-1.744. 
porque no la pisen los que passen o no se la lleven las aves del cielo; antes sea servido que caiga en buena tierra $i$ se multiplique el fruto... ${ }^{16}$

No consiguieron las plegarias del prelado allanar el terreno al padre Micó, hasta el punto de quedar prácticamente suspendidas sus prédicas en febrero de 1542. El dominico pidió licencia para regresar al convento de San Onofre, en el que permaneció durante varios meses. Entre sus muros, le sorprendió la noticia de la interrupción temporal del Santo Oficio valenciano, decretada por Carlos I para tratar de garantizar el éxito una nueva campaña evangelizadora, cuya dirección recaería precisamente en é $1^{17}$. A finales de mayo de 1543, el virrey don Fernando de Aragón, duque de Calabria, giraba un billete al interesado comunicándole su designación

«Como los nuevos convertidos de la secta de Mahoma a la santa fe christiana tengan mucha necessidad de ser enseñados en la dotrina evangélica por alguna persona docta en ella, y para esto seáys vos como tal eligido, esperando que de vuestra predicación se seguirá gran fruto a los dichos christianos nuevos $\rangle^{18}$.

En su misión, gozaría fray Juan de total libertad para predicar, enseñar e instruir en la fe católica a los criptomusulmanes que se hallaren dentro de las fronteras del reino de Valencia, contando con el auxilio de los oficiales del lugar, quienes compelerían a esta población a reunirse en las iglesias o casas señaladas para oír la doctrina cristiana. Junto a ello, el padre Micó llevaría consigo una carta del mismísimo soberano -con una segunda misiva del obispo de Calahorra- para las autoridades de las aljamas apelando a su colaboración para bien del interés general.

Dicho y hecho, en el mes de octubre reiniciaba el dominico su predicación por uno de los núcleos de mayor concentración morisca, el raval de Xàtiva, donde anduvo hasta finales de año procurando arrancar de las huestes mahométicas a hombres, mujeres y niños. Los testimonios conservados sobre su estancia en aquella localidad arrojan unos resultados en nada diferentes a los obtenidos en anteriores predicaciones, pues

«...por más que el santo..., con ardentíssimo zelo, se aplicó a reducir la terquedad obstinada de los moriscos, fue cortíssimo o ninguno el fruto de su apostólica predicación. Los más de ellos, o todos, eran sacrílegos apóstatas i mortales enemigos de la fe de los christianos, ni deseavan otro que, con fingidos y frivolos pretextos, ganar tiempo para sublevarse, socorridos de los de África, y recobrar este reyno que antes dominaron sus ascendientes $\rangle^{19}$.

En tales circunstancias, el religioso fue autorizado, por vez segunda, a regresar a sus quehaceres en la orden al ser elegido prior del convento de Predicadores de

16. BUV: Ms. 933, TEIXIDOR, José: Necrologio de este real convento de Predicadores..., tomo II, pp. 296297.

17. Diago, Francisco: Op. cit., f. 90.

18. FONSECA, Damián: Justa expulsión de los moriscos de España, con la instrucción, apostasía y trayción dellos y respuesta a las dudas que se ofrecieron acerca desta materia, Roma: Jacomo Mascardo, 1612, p. 24.

19. BUV: Ms. 933, TEIXIDOR, José: Necrologio de este real convento de Predicadores..., tomo II, p. 301. 
Valencia, en mayo de 1544, y vicario provincial, quince meses después, sustituyéndole al frente del apostolado morisco su hermano de hábito fray Juan Nublado, cuyo repentino fallecimiento en la corte apenas si le permitió tomar el testigo ${ }^{20}$.

El padre Micó andaba aquellos días reunido en el capítulo dominicano de Tarragona, recordado por la aprobación del convento de Santa Cruz de Llombai, tierra de cristianos nuevos ${ }^{21}$. La fundación había comenzado a levantarse en 1543 a instancias del señor del lugar, don Francisco de Borja, duque de Gandia, criado a los pechos de la orden de Predicadores en expresión de sus biógrafos ${ }^{22}$. El noble se hallaba bajo la dirección espiritual del propio fray Juan, con quien, además de costumbres piadosas, compartía preocupación por la conversión de los moriscos, que se contaban por centenares entre los vasallos del futuro General de la Compañía de Jesús ${ }^{23}$. Siguiendo el ejemplo del conde de Albaida -con la erección del monasterio blanquinegro de Santa Ana en 1538, amparada por el entonces Provincial de Aragón, no otro que el padre Micó $^{24}$ - quiso Borja confiar a los hijos del patriarca de Caleruega la salvación de tantas almas perdidas. Con tal motivo, había conseguido para su establecimiento religioso un breve papal, fechado en diciembre de 1544, otorgándole la condición de rectoría de todo el marquesado de Llombai, con las iglesias anexas de Catadau, Alfarb y Alédua ${ }^{25}$.

Cedido a la orden de Predicadores y bendecido por el Provincial fray Juan Izquierdo, el convento fue oficialmente inaugurado el 16 de junio de 1548 con una primera misa presidida por don Francisco, empeñado durante las semanas siguientes en colocar a fray Juan Micó en la dirección de Santa Cruz. Efectivamente, el dominico se convertiría, muy a su pesar según las crónicas de la orden, en superior de la nueva comunidad, consagrada a la cristianización de los fieles de Mahoma que moraban en el marquesado, sobre la que el religioso comenzaba a albergar dudas después de sus

20. BUV: Ms. 204, FALCÓ, Jaime: Historia de algunas cosas más notables pertenecientes a este convento de Predicadores de Valencia, p. 217.

21. Las correspondientes actas dirían al respecto: «Acceptamus domus Sancta Crucis de Lombay per illustrem ducem de Gandiae edificatam auctoritate reverendissimi olim Generali frater Alberti de Casaus, et damus ibi in vicarium Raphaelem Castello». AHPDA: Ms. 4, Acta capituli provincialis. Tarragona $M D X X X X V$, sf.

22. En concreto, Ribadeneyra, Pedro: Vida del padre Francisco de Borja, que fue duque de Gandia y después religioso y tercero General de la Compañía de Jesús, Madrid: En casa de la biuda de Pedro Madrigal, a costa de Juan de Montoya, 1595, lib. I, cap. 9; y CiEnfuEGos, Álvaro: La heroica vida, virtudes y milagros del grande san Francisco de Borja, Bilbao: Francisco Medel del Castillo, 1726, lib. II, cap. 2.

23. Por cierto, sobre la dimensión jesuítica del problema morisco no nos resistimos a citar a MEDINA, Francisco de Borja: «La Compañía de Jesús y la minoría morisca (1545-1614)», Archivum Historicum Societatis Iesu, Roma, 1988, LVII, pp. 3-136.

24. El cenobio fue aceptado aquel mismo año. AHPDA: Ms. 4, Acta capituli provincialis. Calatayud $M D X X X V I I I I$, sf. Meses después, era el capítulo general reunido en Roma el que ratificaba esta decisión. Acta capitulorum generalium ordinis Praedicatorum, Roma: Ex typographia polyglota SC de Propaganda Fide, 1903, vol. IV, p. 281.

25. Ibid.: p. 628. 
dos experiencias anteriores en esta materia. El 21 de septiembre inauguró su mandato dispuesto a ganar para la Iglesia al rebaño encomendado, y

«...para predicarles con mayor eficacia, aprendió la lengua arábiga, que era la común i usual de los moriscos. Predicóles por mucho tiempo con grande espíritu. Instruíales en la fe i confutava con tan vivas razones su secta que quedavan convencidos, pero no convertidos, sus alfaquies, diciendo estos a la gente común que el prior Micó sabía toda su ley $i$ la entendia tan bien como ellos, i la destruýa de forma con sus argumentos, que no sabian responderle. Pero para su voluntad endurecida, poco o nada aprovechavan las razones convincentes del santo» ${ }^{26}$.

Confirmados sus peores temores, fray Juan tardó todavía algunos meses en arrojar definitivamente la toalla, recurriendo entretanto a otros medios menos ortodoxos a fin de conmover el ánimo de su grey

«Un día entre otros, llegó a predicar a todas las aljamas del marquesado con tanto fervor y tan viva fe que les dixo públicamente en el púlpito: Si os obligáredes a creer como verdaderos christianos, yo me obligo a resucitar el primer muerto que me traxéredes. $Y$ fueron tales que no le tomaron la palabra» ${ }^{27}$.

Nadie pudo retener por mucho más tiempo en Llombai al padre Micó. Ni siquiera el nuevo arzobispo de Valencia, fray Tomás de Villanueva, comprometido con la cuestión morisca a partir de la prosecución de las predicaciones y el aumento y promoción de las rectorías de cristianos nuevos ${ }^{28}$. El prelado agustino, que había conocido muy probablemente a fray Juan en sus tiempos como estudiante en Salamanca, sólo pudo certificar la marcha del dominico, el 2 de diciembre de 1549, para ocuparse otra vez del convento de Predicadores de la capital. Como prior de éste, el religioso tuvo ocasión de reencontrarse con Villanueva para darle cuenta «de todo el discurso de su predicación, de los errores de los moriscos y de su poca o ninguna esperança que avía de su christianísmo... ${ }^{29}$ Sobre todo ello volvería a insistir en mayo de 1550 en los sermones pronunciados con motivo del saqueo berberisco de Cullera ${ }^{30}$.

26. BUV: Ms. 933, TEIXIDOR, José: Necrologio de este real convento de Predicadores ..., tomo II, pp. 308-309.

27. Tan popular episodio con tintes prodigiosos, que refirió por vez primera fray Francisco Diago, a partir de las testimonios del proceso instruido en 1583 para promover la beatificación de su protagonista, sería recogido y engrandecido por posteriores historiadores de la orden de santo Domingo, como los padres Fonseca, Falcó y Teixidor, o ajenos a ella, particularmente mosén Gaspar Escolano. La misma tradición refiere como aquellos mismos moriscos llorarían años después la desaparición del religioso exclamando « Es muerto el santo, es muerto el santo!». Sacro diario dominicano, en el qual se contiene una breve insinuación de las vidas de los santos, beatos y venerables de la orden de Predicadores para cada día del año, con alguna reflexión y oración, traducido de italiano en español y añadido por el muy reverendo padre maestro fray Francisco Vidal y Micó, Valencia: Joseph Thomas Lucas, 1747, p. 401.

28. Benítez SÁnCHEZ-Blanco, Rafael: «El arzobispo Tomás de Villanueva y los moriscos valencianos: juntas, memoriales y mixtificaciones», en Politica, religión e Inquisición en la España Moderna. Homenaje a J. Pérez Villanueva, Madrid: Universidad Autónoma, 1996, pp. 107-128.

29. FONSECA, Damián: Op. cit., p. 27.

30. Diago, Francisco: Op. cit., f. $92 \mathrm{v}$. 
En sus últimos años de vida, el padre Micó permaneció distanciado de una causa que creía perdida, orientando sus preocupaciones misionales ya no tanto a la conversión de los paganos de la tierra patria, sino a los de allende del océano ${ }^{31}$. Sabía, sin embargo, que el Nuevo Mundo era cosa de jóvenes, como su más aventajado discípulo san Luis Bertrán, futuro apóstol de las Indias, quien tampoco pudo sustraerse de la delicada tesitura generada por los mahometanos valencianos.

\section{UN SANTO DESCORAZONADO}

De fray Luis Bertrán y los moriscos se ha dicho tradicionalmente que «nunca le llamó su spíritu a predicar de assiento a esta gente, teniéndolo, como él mesmo dezía, por tiempo perdido, añadiendo que en los que no querían oyr, no podía aver aparejo para creer sin muy particular ayuda y favor del Spíritu Santo» ${ }^{32}$. El dominico hablaba por conocimiento propio, sin duda. Recién hecha su profesión religiosa en el convento de Predicadores de Valencia, había acompañado al padre Micó hasta Llombai, por deseo expreso de éste, para hacer prevalecer el cristianismo entre sus habitadores $^{33}$. Con él regresaría a la capital tiempo más tarde para ocupar, a finales de la década de 1550, el priorato de Santa Ana de Albaida. Palomar, Agres, Bélgida Alcoi y Cocentaina, por citar sólo algunos ejemplos, fueron escenarios destacados de sus prédicas a los criptomusulmanes. Convencido de la inutilidad de nuevas tentativas evangelizadoras en el reino, fray Luis puso tierra de por medio para misionar al otro lado del Atlántico a partir de 1562, con motivo de la fundación de la Provincia dominicana de San Antonino de Nueva Granada ${ }^{34}$.

De vuelta en casa siete años después, los nuevos convertidos volvieron a interponerse en su camino cuando el recién nombrado arzobispo de Valencia, don Juan de

31. Soler, Abel, y Terol, Vicent: $O p$. cit., p. 420. A su muerte, acaecida en 1555, los frailes del convento de Predicadores hallaron junto a su lecho un volumen de manuscritos sobre el tema recopilados por el difunto para su encuadernación. Entre los papeles hallados, se encontraba un primera redacción de la más conocida obra de fray Bartolomé de Las Casas. De rebus Indiis deplorandis. La Brevísima y otros manuscritos sobre las Indias en la Valencia de la primera mitad del siglo XVI. Valencia: Biblioteca Valenciana, 2008.

32. FONSECA, Damián: Op. cit., pp. 36-37. Una primera aproximación al tema en GALMÉS MAS, Lorenzo: «La cuestión de los moriscos en la época de san Luis Bertrán», en Corrientes espirituales en la Valencia del siglo XVI (1550-1600), Valencia: Facultad de Teología San Vicente Ferrer, 1982, pp. 291-300.

33. Véanse al respecto las biografías clásicas del santo, particularmente la de ANTIST, Vicente Justiniano: Verdadera relación de la vida y muerte del padre fray Luis Bertrán, de bienaventurada memoria, Zaragoza: Juan Alterach impresor, 1583, p. 98, y VIDAL Y MICÓ, Francisco: Historia de la prodigiosa vida, virtudes, milagros y profecías del segundo Ángel del Apocalipsis y apóstol valenciano de las Indias Occidentales san Luis Bertrán, Valencia: Oficina de José Tomás Lucas, 1743, p. 68. Sobre ellas y otras, Callado Estela, Emilio, y Esponera Cerdán, Alfonso: «San Luis Bertrán. Un dominico en tiempos de reforma», en Valencianos en la Historia de la Iglesia II, Valencia: Facultad de Teología San Vicente Ferrer, 2008, pp. 137 y ss.

34. GalmÉs MAs, Lorenzo: Un misionero valenciano en Colombia: San Luis Bertrán, Valencia: Provincia dominicana de Aragón, 1982. 
Ribera, le tomó entre sus colaboradores para afrontar los asuntos más urgentes que reclamaban la atención episcopal ${ }^{35}$; entre ellos los derivados de esta minoría, frente a la cual el prelado acabaría experimentando una evolución muy similar a la seguida por el religioso ${ }^{36}$. En 1574, todavía reciente la rebelión de los moriscos de Granada y con el temor a una alianza entre la comunidad interior y los turcoberberiscos, el rumor de que la morisma preparaba un ataque contra la ciudad sembró el pánico en el cap $i$ casal. El padre Bertrán se empleó a fondo en tranquilizar a la población, asegurando a los valencianos con espíritu profético que «no tomassen pesar, ni tenían que moverse de su casa, porque los moros ni venían ni vendrían a Valencia.... $\rangle^{37}$

A pesar de sus palabras, ni el mismo dominico debía de tenerlas todas consigo. No se entendería, de lo contrario, que en 1577 hiciera llamar a su celda al señor de Borriol, don Juan Boïl de Arenós, del que era confesor, para representarle el peligro inmimente en que se hallaba la Monarquía entera, en lo espiritual y lo temporal, mayor incluso que el de los tiempos del rey Rodrigo, al contar en sus entrañas con una quintacolumna del islam. Fray Luis propuso al noble que viajase de inmediato a la corte para suplicar a Felipe II y sus consejeros «echasse a los moros de España, porque los más de los moriscos bautizados eran sacrílegos, apóstatas y mortales enemigos de la fe, deseando sublevarse con fingidos pretextos para recobrar estos reynos que antes dominaron sus ascendientes». Hasta tres veces trató de declinar el encargo don Juan, que finalmente partió a Castilla llevando el encargo del religioso ${ }^{38}$.

Un par de años después, el padre Bertrán, como prior entonces del convento de Predicadores y a petición del virrey de Valencia, don Pedro Manrique de Lara, duque de Nájera, tenía ocasión de exponer personalmente a la corona su parecer a propósito de los cristianos nuevos, «assi en orden a la vida y costumbres desta gente, como acerca del remedio que este mal podía tener». La desesperanza habló por boca del

35. Garganta, José María: «San Juan de Ribera y san Luis Bertrán», Teología Espiritual, Valencia, 1961, vol. V, pp. 63-104.

36. En relación al Patriarca y los moriscos pueden consultarse los trabajos de MESTRE SANCHIS, Antonio: «Un documento desconocido del Patriarca Ribera escrito en los momentos decisivos sobre la expulsión de los moriscos», en Estudios dedicados a Juan Peset Aleixandre, Valencia: Universidad de Valencia, 1982, pp. 733-739; SEguí CANTOS, José: «La razón de Estado: Patriarca Ribera y moriscos (1599-16091999)», Estudis, Valencia, 1999, no 25, pp. 90-109; y sobre todo BENíTEZ SÁNCHEZ-Blanco, Rafael, particularmente «Felipe II y el arzobispo Ribera ante la evangelización de los moriscos valencianos», en La Monarquía de Felipe II a debate, Madrid: Sociedad Estatal para la Conmemoración de los Centenarios de Felipe II y Carlos V, 2000, pp. 405-425; y Heroicas decisiones. La Monarquía católica y los moriscos valencianos, Valencia: Institució Alfons el Magnànim, 2001, pp. 311-420.

37. Así lo declararía doña Francisca Beneyto, esposa del caballero del mismo apellido, en el proceso informativo para la beatificación del religioso instruido en 1596. Procesos informativos de la beatificación y canonización de san Luis Bertrán, Valencia: Provincia dominicana de Aragón, 1983, p. 213.

38. Y desde entonces, añaden las crónicas dominicanas, «se començó a tratar con gran calor la expulsión de los moriscos». VIDAL Y Micó, Francisco: Op. cit., p. 182. Sabemos cierto, al menos, que en fecha posterior, ya iniciado el Seiscientos, la junta integrada por el confesor real fray Gaspar de Córdoba, el comendador mayor de León don Juan de Idíaquez y el conde de Miranda, analizaría detenidamente la referida exposición. BEníTEZ SÁnCHEZ-Blanco, Rafael: Heroicas decisiones ..., pp. 356-357. 
dominico en el correspondiente dictamen escrito ${ }^{39}$. En él, expresó su firme convicción de que los moriscos no eran sino herejes y apóstatas, por cuanto habían sido bautizados válidamente, con independencia de la forma en que recibieran este sacramento, pues

«...no es bastante escusa desto dezir que los baptizaron por fuerça en tiempos de las comunidades y después, aunque aquello no fue bien hecho y pluguiera a Dios que nunca se hiziera, que bien se ha mostrado quanto mejor fuera seguir la costumbre de la Iglesia. Pero muchos de los que recibieron por fuerça el baptismo, consintieron en alguna manera, quanto más que de las veynte partes de los moriscos qua oy viven, las diez y nueve han recibido el baptismo siendo niños, y assí, sin duda alguna..., pueden ser forçados a guardar la fe de Jesuchristo como nosotros los christianos viejos, ni más ni menos» ${ }^{40}$.

Los desmanes perpetrados por estas gentes contra los mandamientos de la ley de Dios y de la Iglesia católica, de los que él mismo había sido testigo, se habían prolongado durante el último medio siglo con total impunidad, «y si no es quien quiera cerrar los ojos del todo, les verá por todos los lugares». Para paliar semejante situación, fray Luis proponía dos remedios. El primero, pasaba necesariamente por prohibir el empleo de la lengua árabe en estas comunidades,

«...es menester quitarles el hablar en algaravía porque de ahi viene que los niños y las mugeres no se conviertan a la fe porque no entienden a los predicadores y confessores. Podriase remediar esto mandando que ningún morisco, entrando en ciudad alguna, villa o lugar de christianos deste reyno, hable algaravía; y que las mugeres no se puedan casar si no saben la dotrina christiana; y que los domingos y fiestas, siempre que van a la iglesia ellos o ellas, paguen un tanto si hablan algaravía» ${ }^{41}$.

Los sacrilegios cometidos recomendaban, en segundo término, que no se administrara el sacramento del bautismo a los niños moriscos salvo peligro de muerte, pues «más vale que sean moros que hereges y apóstatas», como con toda certeza acabarían siéndolo a lo largo de su vida. En cualquier caso, la complejidad del asunto de los nuevos convertidos debía someterse al juicio del papa, quien tenía la última palabra al respecto

«...lo más acertado será suplicar a su magestad que mande proponer este negocio clara y distintamente delante del vicario de Jesuchristo, para que su santidad determine lo que se ha de hacer y el cómo; y assí se eviten tantas blasfemias contra la magestad Nuestro Señor, y por consiguiente, aplaque Dios su ira y no nos imbie tantos castigos de hambre y

39. El autógrafo de este documento, custodiado en su día en el archivo del antiguo convento de Predicadores de Valencia, se perdió durante los avatares políticos acaecidos a partir de 1808. CALlADO EsTELA, Emilio, y ESPONERA CERDÁN, Alfonso: «Aproximació històrica a l'arxiu i biblioteca del Reial Convent de Predicadors de València...», pp. 95 y ss. Sabemos de su contenido, no obstante, por las copias conservadas en otras instituciones, particularmente el Instituto Valencia de don Juan (Madrid), envío 1, pieza 183, así como las incluidas en las obras clásicas sobre el tema, de autoría blanquinegra, citadas a lo largo de estas páginas. La edición moderna del mismo, no siempre fiel al original, en RoBLES SIERRA, Adolfo: «Correspondencia de san Luis Bertrán», en San Luis Bertrán. Reforma y Contrarreforma española, Valencia: Provincia dominicana de Aragón, 1973, pp. 347-348.

40. Ibid.

41. Ibid. 
esterilidad como en este Reino padecemos... y lo mismo sienten algunos padres muy doctos deste convento (de Predicadores) con quien lo he platicado» ${ }^{42}$.

La muerte del padre Bertrán en 1581 se adelantó en casi tres décadas al desenlace final de esta historia, anunciado por él mismo a sus hermanos de hábito en una de sus últimas profecías, según la cual a los hijos de Mahoma «el rey nuestro señor no los desterrará, pero nacerle ha un hijo tan celoso de la fe y de la honra de Dios que los echará deste reyno y de toda España... $\rangle^{43}$

La defección de la más significativa figura dominicana de la época no impidió, sin embargo, que buena parte de la orden de Predicadores, incluidos muchos discípulos del futuro santo, se resistiera todavía en las últimas décadas del Quinientos a renunciar a los medios suaves como forma de aproximación a los cristianos nuevos. Así lo confirmaría la nueva oleada de fundaciones cenobiales, cuyos orígenes estuvieron vinculados de una u otra manera a la evangelización de esta minoría, en la que decenas de frailes blanquinegros continuaron implicados, ya fuera a través de las parroquias o como misioneros.

\section{CONVENTOS, PARROQUIAS Y MISIONEROS}

Entre 1578 y 1595 siete nuevos conventos dominicos aparecieron en zonas de moriscos ${ }^{44}$. El de Ayodar fue el primero de ellos ${ }^{45}$, seguido unos meses después por los de L'Olleria, levantado sobre la ermita de Nuestra Señora de Orito ${ }^{46}$, y el de Nuestra

42. Ibid.

43. BledA, Jaime: Corónica de los moros de España..., p. 976. Curiosamente, el nombre de fray Luis pasaría a la posteridad vinculado a la expulsión morisca, cuyo patrocinio le atribuyó erróneamente VIDAL Y MiCó, Francisco: Op. cit., pp. 387-388. La causa del yerro habría que buscarla en la obra del padre BLEDA, Jaime: Defensio fidei in causa neophitorum sive morischorum regni Valentiae, totiusque Hispaniae, Valencia: Ioanem Chrysostorum Garriz, 1610. Y más concretamente en una precipitada lectura del siguiente párrafo: «Ille in coelo hanc suae patriae redemptionem obtinuit mox in beatos relatus. Fuit ascitus et electus patronus huius regni anno 1608, et non est passus morischos in eodem regno manere integro anno postquam eius suscepit patrocinium» (Ibid., p. 102), en el que el cronista blanquinegro parece referirse no tanto a la designación oficial del entonces beato como patrón especial del extrañamiento, por parte del Consell general capitalino, como a su intercesión en un momento concreto de la puesta en marcha de aquella medida. Fue el primero en llamar la atención sobre ello el padre TEIXIDOR, José: Necrologio de este real convento de Predicadores..., tomo II, p. 486.

44. Diago, Francisco: Op. cit., ff. 292 y ss.

45. Aceptado en el capítulo provincial Tarraconense de 1579. AHPDA: Ms. 4, Acta capituli provincialis. Tarragona MDLXXVIIII, sf. Dos décadas más tarde era elevado a priorato por el cónclave general de Roma. Acta capitulorum generalium ordinis Praedicatorum ..., vol. V, p. 296. Conocemos por el padre Damián Fonseca que en Ayodar la mayoría de los niños moriscos estaban sin cristianar, «y que lo sabía de cierto porque en todos los lugares que están a las riberas del río Mijares, se tenía por costumbre». FONSECA, Damián: Op. cit., pp. 124-125.

46. Las autoridades de la orden lo aceptaron también en el capítulo de 1579, entrando en disputa con el arzobispo de Valencia, opuesto a esta fundación. La Santa Sede intervino a mediados de la década de los ochenta con un breve ratificando el establecimiento dominicano, elevado a la condición de priorato en 
Señora del Rosario, en la ciudad de Castelló de la Plana ${ }^{47}$. Bajo esta última advocación, en 1586 y 1587, la orden de Predicadores levantaba en Alacant ${ }^{48}$ y Almenara ${ }^{49}$ otro par de establecimientos religiosos. A comienzos de los noventa dos cenobios más, dedicados ambos a San Vicente Ferrer, se sumaban a la lista, en las localidades de Castelló de la Ribera y Algemesi ${ }^{50}$. Finalmente, un lustro antes de concluir el siglo, llegaría el turno a San Jacinto de Agullent ${ }^{51}$.

Coincidiendo con estos años, el Patriarca don Juan de Ribera reunió en Valencia a petición de la corona una junta de teólogos, pertenecientes a diferentes órdenes religiosas, para abordar el estado de la cuestión morisca ${ }^{52}$. Algunas voces se mostraron favorables al otorgamiento de un edicto de gracia para con los mahometanos a fin de facilitar su arrepentimiento. Contra esta medida se pronunció el representante de los dominicos y prior del convento de Predicadores, fray Vicente Justiniano Antist, hijo espiritual y primer biógrafo de fray Luis Bertrán ${ }^{53}$. La opinión del padre Antist - una excepción entre sus hermanos de generación- fue desestimada, solicitándose a la Santa Sede el indulto propuesto que no llegaría sino tiempo después. De momento, se adoptó un plan para la instrucción de los cristianos nuevos basado en la acción parroquial, para la que el arzobispo reclamó la colaboración del clero regular en general, y de los hijos de santo Domingo muy particularmente. Fue así como numerosos frailes blanquinegros ejercieron como rectores de iglesias de población morisca hasta entrada la nueva centuria $^{54}$. Ahí están los nombres de los padres Juan Lorenzo, en Barxeta; Bartolomé Xucart, en Benavites; José Aliaga y Luis Salvador en Benirrama; Jerónimo Satorre en

1593. Más detalles en Colell, Alberto: «Ayer de la Provincia dominicana de Aragón», Analecta Sacra Tarraconensia, Barcelona, 1968, vol. XXXIX, p. 241.

47. Los permisos de la orden en AHPDA: Ms. 4, Acta capituli provincialis. Tarragona MDLXXVIIII..., sf.

48. El alicantino convento de Nuestra Señora del Rosario y San Pedro González Telmo quedó aprobado en Valencia en 1588. Ibíd.: Valencia MDLXXXVIII, sf. El capítulo general del año siguiente, reunido en Roma, así lo certificaba. Acta capitulorum generalium ordinis Praedicatorum ..., vol. V, p. 398.

49. Igualmente, fue autorizado por el capítulo provincial valentino del año 1588. AHPDA: Ms. 4, Acta capituli provincialis. Valencia MDLXXXVIII..., sf., reconociéndosele como priorato en 1599. Acta capitulorum generalium ordinis Praedicatorum ..., vol. V, p. 296.

50. A propósito de ambas fundaciones AHPDA: Ms. 4, Acta capituli provincialis. Zaragoza MDLXXXXII, sf.

51. COLELl, Alberto: Art.cit., p. 243.

52. La Junta de 1587 en HALPERIN DONGHI, Tulio: Un conflicto nacional. Moriscos y cristianos viejos en Valencia, Valencia: Institució Alfons el Magnànim, 1980, pp. 189-193.

53. FONSECA, Damián: Op. cit., pp. 39-40. Sobre la interesante personalidad y obra de este historiador dominico véase FUENTES, Celedonio: Escritores dominicos del reino de Valencia ..., pp. 28-36; ROBLES SIERRA, Adolfo: «La biografía inédita de san Ramón de Penyafort escrita por Vicente Justiniano Antist o.p. (s. XVI)», Escritos del Vedat, Torrent, 1977, vol. VII, pp. 29-31; RoBLES, Laureano: «Vicente J. Antist, o.p., y su opúsculo De viris illustribus'», Revista Española de Teología, Madrid, 1979-1980, $\mathrm{n}^{\circ}$ 39-40, pp. 200-224; y ESPONERA CERDÁN, Alfonso: «El valenciano Vicente Justiniano Antist op y su inédita Historia de la santa Inquisición (1589-1592)», en Vivir en la Iglesia. Homenaje al profesor Juan Agulles, Valencia: Facultad de Teología, 1999, pp. 493-519.

54. RobRes LluCH, Ramón: «Predicadores de moriscos en el pontificado de san Juan de Ribera (15691609)», en Corrientes espirituales..., pp. 301-309. 
Cirat; José Quesada y fray Juan Pavía en Cortes de Arenós; Gaspar Pavía y Pedro Giner en Espadilla; o el controvertido Jaime Bleda -de quien más adelante se hablará- en Aielo de Malferit, Alcocer, Gavarda y Corbera.

Otros tantos religiosos, aún sin hallarse vinculados a estas parroquias, ejercieron también labores misionales a lo largo y ancho del reino como auxiliares de la mitra. Los hubo menos conocidos, como fray Luis Primo y fray Bartolomé Comas, a los que Ribera libró diferentes cantidades por sus predicaciones en distintos lugares de la diócesis. O más populares, caso de los padres Miguel Lázaro y Domingo Anadón, dos vidas paralelas consagradas a la predicación ${ }^{55}$. Aragoneses de la zona de Daroca, habían profesado muy jóvenes en el convento de Predicadores de Valencia, donde ejercieron como maestro de novicios y portero, respectivamente, después de haberse forjado en la escuela viva de su mentor, fray Luis Bertrán ${ }^{56}$.

Las artes de uno y otro en el púlpito no pasaron desapercibidas al Patriarca, reclutándoles para sus proyectos evangelizadores. En la campaña episcopal de 1600-1601 por tierras de infieles, el prelado se hizo acompañar de ellos. Llegados a Bétera, el padre Lázaro hubo de soportar las impertinencias de sus vecinos; entre otras, «le dixo uno dellos: padre ¿a qué venís?. Y respondiendo él que yva a predicarles el Evangelio, dixo el christiano nuevo: Ea, padre, que por fuerça avíades de començar por aquí?, como si fuera el predicar pedirles algún grave tributo» ${ }^{57}$. A fray Domingo, por su parte, no quedó más solución que rememorar el episodio atribuido por la tradición al padre Juan Micó para llamar la atención de la población de Benaguasil

«...les predicó más de media hora. Y enardeciéndose de calidad en el zelo de la fe...les dixo: Mirad para confirmación de la santa fe que os predico quál de vuestros antipassados difuntos queréis que os resucite en testimonio de su verdad, que como queráis convertiros de coraçón a la fe de Christo, y os lo ofresco de parte de Dios resucitar este tiempo. Thomás Taix, presbytero, que estava sentado al lado de Gerónimo Jerrín, morisco, Justicia del lugar, le dixo: Jerrin, ahora es hora que pidas la resurrección de tu padre, que ha muerto hogaño. A lo que el morisco, muy a lo hypócrita, respondió: Todos somos christianos. Enmudeció a esta tan grandiosa oferta todo aquel obstinado comando de moriscos, los quales estavan tan tercos en su secta ... $\rangle^{58}$

No necesariamente los misioneros dominicos ejercieron su ministerio a las órdenes de don Juan de Ribera, haciéndolo, en muchas ocasiones, por voluntad propia o

55. Una breve reseña biobliográfica sobre ambos en FUENTES, Celedonio: Escritores dominicos del reino de Aragón, Zaragoza: Imprenta Editorial Gambón, 1932, pp. 48-53.

56. VidAL Y Micó, Francisco: Op. cit., pp. 480 y 495.

57. GóMEZ, Vicente: Breve relación de las virtudes y santa vida del padre fray Miguel Lázaro, de buena memoria, (editada junto a la Verdadera relación de la vida, muerte y hechos milagrosos del bendito padre fray Domingo Anadón), Valencia: Junto al molino de Rovella, 1607, p. 270.

58. TOMÁs MiQUel, Serafín: Compendio de la vida y virtudes del venerable padre fray Domingo Anadón, portero y limosnero del insigne y real convento de Predicadores de Valencia, Valencia: Juan Gonçález, 1716, pp. 33-41, elaborado a partir de los datos proporcionados por el proceso informativo instruido para promover la beatificación del dominico, conservado en el Archivo del Real Convento de Predicadores de Valencia (ARCPV): Ms. 65. 
disposición de las autoridades de la orden. Fray Jacinto Fonseca -a quien no debe confundirse con el padre Damián de igual apellido, protagonista de páginas posterioresfue de los primeros, y como tal, testigo excepcional de varios portentos relacionados con la minoría conversa acaecidos en La Vall d'Albaida, lugar habitual de sus sermones. En 1602 predicaba a estas gentes junto al convento de Corpus Christi de Llutxent, cuando el auditorio allí reunido para escucharle sintió «súbitamente en el ayre gran ruydo de atabales y caxas de guerra que tocavan milagrosamente el arma, quiçá para hazer gente contra estos enemigos de la fe». Un año después, esta vez en Castelló del Duc, las blasfemias proferidas por un cristiano nuevo en la plaza del pueblo habrían desatado una tormenta que elevó al sacrílego por los aires dejándolo caer al suelo desde más de cien metros de altura, desnudo y con los ojos arrancados. Cuentan sus hermanos de hábito que fray Jacinto intensificó sus prédicas a raíz de los sucesos descritos,

«...para que, con esta ocasión, viesse si podía ablandar los pechos endurecidos de los moriscos, como lo intentó predicándoles un famoso sermón..., exortándoles a que considerassen como todos los elementos se conjuravan contra ellos y bolvian por el honor de su Criador, al qual ellos tenían tan ofendido; y que, si no se enmendavan, los avía de castigar Dios rigurosamente, como començava ya a hazer. Pero los moriscos estavan tan obstinados que no sólo no hazía fruto la Palabra de Dios senbrada en aquellos coraçones de piedra, antes inquietavan el auditorio de manera que tenía harto que hazer el alguazil en sosegarlos; y deshaziéndose en lágrymas el predicar y los christianos que estavan en el auditorio, ellos se quedavan riyendo» ${ }^{59}$.

Con el padre Fonseca compartió responsabilidad en la cruzada morisca -siguiendo instrucciones esta vez de sus superiores- fray Pedro del Portillo, aragonés prohijado en el convento de Predicadores de Valencia bajo el magisterio del padre Luis Bertrán y la compañía de los ya mencionados fray Miguel Lázaro y fray Domingo Anadón ${ }^{60}$. El religioso había sido uno de los primeros priores del convento dominicano de Ayodar, cuya dirección le encomendó el padre Miguel Rubinat, Provincial de Aragón, para velar por la instrucción de los nuevos convertidos. De allí pasó, con idéntico cometido, a las recién inauguradas instalaciones blanquinegras de Castelló de la Plana y más tarde a las de Santo Domingo de Teruel, donde le sorprendería la expulsión. En todos sus destinos, demostró una especial sensibilidad hacia los niños, a quienes gustaba adoctrinar en la verdadera fe con palabras sencillas, cariño y algún que otro juego, llegado el caso $^{61}$.

No como misionero, sino en calidad de obispo, iba a desempeñar un papel crucial en los últimos tiempos de la comunidad morisca otro dominico hijo espiritual bertraniano, fray Andrés Balaguer.

59. FONSECA, Damián: Op. cit., p. 169.

60. VIDAL y MicÓ, Francisco: Op. cit., pp. 480-483.

61. FUENTES, Celedonio: Escritores dominicos del reino de Aragón..., pp. 69-70. 


\section{EL OBISPO BALAGUER}

Natural de La Jana, el padre Andrés Balaguer fue prior de los conventos dominicanos de Sant Mateu, Ontinyent y Valencia, donde años atrás había vestido el hábito para recibir las enseñanzas de fray Luis Bertrán ${ }^{62}$. Vicario general de la Provincia de Aragón durante un tiempo, inspeccionó por encargo de Felipe III varios conventos barceloneses, quedando tan satisfecho el monarca con sus servicios que le presentó para la mitra de Albarracín en 1602. Desde el primer día de su pontificado, el religioso se mostró preocupado por los cristianos nuevos, numerosos en aquella Iglesia y aglutinados en las poblaciones de Gea, Bezas y el Barrio Nuevo de la misma ciudad de Albarracín. Con motivo de la visita pastoral a las veintiocho parroquias que integraban la sede, pudo dar testimonio de las consecuencias derivadas de las falsas conversiones, contra las que promulgaría ya en 1603 algunas ordenaciones.

Con tales antecedentes, era de esperar que el prelado volviera a ocuparse de este asunto en el sínodo diocesano reunido a mediados del año siguiente ${ }^{63}$. Y lo haría en su título XLIV, empezando por los recién nacidos, quienes debían ser atendidos por parteras cristianas viejas, capaces de administrarles el bautismo caso de peligrar sus vidas ${ }^{64}$. Cuando la edad lo permitiera, estos niños acudirían a la escuela, «porque para enseñança de los nuevamente convertidos importa mucho que, desde pequeños, sepan leer y escrevir y se les enseñe la dotrina christiana». Para ello, se precisaba de maestros, también cristianos viejos y jamás conversos, pero sobre todo diestros en los misterios de la fe y con vocación docente, porque «la experiencia nos enseña que si los niños, de pequeñitos, no son ynstruidos en los principios de nuestra santa fe cathólica por personas idóneas para ello, suelen, quando son grandes, o no saber los mysterios o tener algunos errores, todo lo qual desdize de la verdad de nuestra religión christiana». En los casos de hijos ilegítimos fruto de uniones mixtas, nunca el niño quedaría a cargo del nuevo convertido antes de los veinte años de edad, pues

«...queremos que todo este tiempo estén debaxo de la protección y amparo del padre o madre christianos viejos para que puedan ser enseñados desde niños en los principios de nuestra santa fe, pues según derecho... los que son hijos de diferentes padres han de seguir al que fuere de mejor condición en la fe, y siempre se ha de presumir que están más

62. Los datos proceden de ANTÓN Guillén, Miguel Ángel: «Fray Andrés Balaguer, o.p., obispo de Albarracín y Orihuela (1551-1626)», Escritos del Vedat, Torrent, 1999, vol. XXIX, pp. 165-250.

63. BALAguer, Andrés: Synodo dioecesana celebrada en la ciudad de Santa María de Albarrazín, en el mes de mayo de 1604, Barcelona: Casa de Sebastián de Comellas, 1604. En sus rasgos generales, el contenido legislativo de esta asamblea fue estudiado por ANTÓN GuILLÉn, Miguel Ángel: La cura pastoral sacramental y práctica en el sínodo diocesano de Albarracín del obispo fray Andrés Balaguer, Tesis doctoral inédita, Facultad de Teología de Valencia, 1996; y «Fray Andrés Balaguer...», pp. 200-219. También Benlloch PovedA, Antonio: «Una compilación codicial de 1604. El sínodo de fray Andrés Balaguer, obispo de Albarracín», en La diócesis de Segorbe y sus gentes a lo largo de la Historia, Castelló de la Plana: Fundación Dávalos Flétcher, 2004, pp. 103-111.

64. Balaguer, Andrés: Op. cit., Tit. XLIV. De los christianos nuevos, cap. 2, p. 360. 
instruydos en nuestra fe cathólica los padres que son christianos viejos que los que fueren nuevamente convertidos $\rangle^{65}$.

De tal modo se garantizaría que, cuando estos jóvenes llegaran a la edad de contraer matrimonio, tuvieran unos rudimentos mínimos del cristianismo, que habrían de probar ante el sacerdote oficiante. Con todo, no podrían convivir las parejas bajo el mismo techo sin haberse desposado antes por palabras de presente y escuchado misa $^{66}$. Llegados a este punto, los rectores de las parroquias seguirían velando porque los moriscos vivieran el resto de sus días en el seno de la Iglesia, mediante catequesis, predicaciones y cuantos recursos fueran precisos, ya que «es notoria la grande necessidad que esta gente tiene de ser governada con particular vigilancia y solicitud de sus pastores». Sólo así estarían en condiciones de alcanzar la salvación de sus almas cuando Dios lo dispusiera, pasando antes sus cuerpos por el templo, con las ceremonias y oraciones pertinentes, para recibir después cristiana sepultura ${ }^{67}$.

La experiencia adquirida por el padre Balaguer con los criptomusulmanes albarracinenses debió de influir probablemente en su promoción a la diócesis de Orihuela, otra plaza fuerte morisca vacante por muerte de su titular don José Esteve, impulsor de una red de rectorías para cristianos nuevos ${ }^{68}$. A su llegada a la capital del Bajo Segura, en enero de 1605, el dominico se ocupó de los últimos retoques de este entramado parroquial, que visitó durante los meses posteriores para encontrarse con sus fieles, predicarles el Evangelio y ordenar a los vicarios que «se tratassen con ellos con benignidad, como curas y padres spirituales de sus almas, sin mostrar interés alguno, provando si con estos medios suaves podría reduzir esta gente al menos a que tuviessen afición al obispo y a los retores para que después, con más facilidad, les diessen crédito... ${ }^{69}$

En ello andaba fray Andrés cuando el papa Paulo V le convocó -junto a sus homónimos de Segorbe y Tortosa- a participar en la junta que, presidida por el Patriarca don Juan de Ribera, había de reunirse en Valencia para tratar por enésima vez la cuestión morisca, por momentos más irresoluble ${ }^{70}$. No se iniciaron las sesiones, sin embargo,

65. Ibid.: cap. 6, p. 361.

66. Ibid.: cap. 5 , p. 360.

67. Ibid.: caps. 3-4, pp. 359-360.

68. MARTíneZ VALls, José: «Los moriscos de la diócesis de Orihuela a finales del siglo XVI y la legislación particular canónica sobre los mismos», Anales de la Universidad de Alicante. Facultad de Derecho, Alicante, 1982, n 1, pp. 243-272; y VILAR, Juan B.: «La creación de rectorías en lugares de moriscos de la diócesis de Orihuela por el obispo Esteve, 1597», Sharq al-Andalus, Alicante, 1997-1998, n 14-15, pp. 263-284.

69. FONSECA, Damián: Op. cit., p. 69. En muy similares términos se referiría fray Andrés a la comunidad morisca oriolense tres años después con motivo de la relación sobre el estado de la diócesis remitida a la Santa Sede, y según la cual «sunt undecim oppida seu loca novorum ad fidem conversorum seu moriscorum ex quibus unum quodque suam habet parrochialem ecclesiam et parrochum seu rectoreme qui illos de fide edoceat et illis sacramenta administret». Archivo Segreto Vaticano (ASV): S. Congr. Concilii, Relaciones ad limina. Oriolen. 600 A. 1608, f. 470. Ed. CÁRCEL ORTí, María Milagros: Relaciones sobre el estado de las diócesis valencianas I. Orihuela, Valencia: Generalitat Valenciana, 1989, p. 356.

70. Se hace eco de esta noticia BUV: Ms. 204, FALcó, Jaime: Op. cit., p. 541. 
hasta el 22 de noviembre de 1608, estancándose poco después como consecuencia de la polémica suscitada entre los prelados a resultas de cuatro puntos,

«...el primero, si estos moriscos eran y se devian tener y reputar por notorios herejes y apóstatas de nuestra santa fe cathólica. El segundo, si los hijos destos podian ser baptizados dexándolos en poder de sus padres. El tercero, si convenía supplicar a su santidad concediese facultad a los moriscos para que representassen las dificultades que tienen en la fe, sin que ellos ni los que los oyesen estuviessen obligados a manifestarlo (al Santo Oficio). El quarto, si los prelados podían compeler a éstos a que oyesen missa y a que se confessassen, constando como consta evidentemente que, en ambas cosas, se cometen por ellos gravíssimos pecados y sacrilegios» ${ }^{71}$.

El asunto fue sometido entonces a la opinión de varios teólogos pertenecientes a las principales órdenes religiosas ${ }^{72}$. Entre los consultados, un condiscípulo de los padres Anadón, Lázaro y Balaguer, alumno como ellos de fray Luis Bertrán, y superior por aquellos días del convento de Predicadores de Valencia: el padre Jerónimo Alcocer, muy ilustrado en esta materia desde su paso por las comunidades dominicanas de Santa Cruz de Llombai y Corpus Christi de Llutxent, que dirigió siendo cura, a la vez, de los lugares de cristianos nuevos próximos a los citados cenobios ${ }^{73}$. Fray Jerónimo respondió en esta ocasión que los moriscos eran herejes notorios, cuyos hijos podían y debían, no obstante, ser bautizados, aún quedando en manos de sus padres; respecto a la posibilidad de otorgarles libertad para comunicar sus errores y dudas, se mostró contrario por su segura ineficacia, como inútil era también, en su opinión, emplear la coacción para obligarles a oír misa o confesarse. Extremos todos ellos, a excepción del primero, en los que vino a coincidir con su hermano de hábito, el obispo de Orihuela ${ }^{74}$.

En marzo de 1609 la junta de Valencia daba por concluidas sus sesiones avalando un postrero intento evangelizador jamás materializado tras la muerte, acaecida semanas atrás, de uno de sus más poderosos valedores en la corte: el confesor regio fray Jerónimo Xavierre, eslabón decisivo en la cadena de dominicos que habían dirigido la conciencia del soberano desde comienzos de su reinado, convirtiendo a la orden de Predicadores en la de mayor influencia política de la Monarquía ${ }^{75}$.

\section{CUATRO CONFESORES PARA UN REY}

No parece que los primeros confesores de Felipe III se mostraran proclives a las medidas radicales para con los nuevos convertidos escuchadas desde comienzos de

71. Cit. Benítez SÁnchez-Blanco, Rafael: Heroicas decisiones..., p. 386.

72. ESCOLANO, Gaspar: Op. cit., cols. 1.827-1.834.

73. BLedA, Jaime: Corónica de los moros de España..., p. 957.

74. Boronat y BARRACHINA, Pascual: Los moriscos españoles y su expulsión. Estudio histórico crítico, Valencia: Imprenta de Francisco Vives y Mora, 1901, vol. II, pp. 137-138.

75. Alonso Getino, Luis G.: «Dominicos españoles confesores de reyes», La ciencia tomista, Salamanca, 1916, vol. XIV, pp. 374-451. Para ambos casos véase por igual MARTínEZ PEÑAS, Leandro: El confesor del rey en el Antiguo Régimen, Madrid: Editorial Complutense, 2007, pp. 366-382 y 382-388, respectivamente. 
siglo en determinados ámbitos políticos, actitud que valdría a fray Gaspar de Córdoba y fray Diego Mardones -que lo fueron por su parte hasta 1604 y 1606- algún que otro enfrentamiento con el favorito del monarca, don Francisco Gómez de Sandoval, duque de Lerma ${ }^{76}$. Su sucesor, el padre Jerónimo Xavierre, superó a ambos religiosos en contundencia frente a semejantes soluciones, antes incluso de llegar al confesionario, como Provincial de Aragón o Maestro general de la orden de Predicadores ${ }^{77}$. Ocupando todavía esta última dignidad, fray Jerónimo se opuso a la expulsión en la junta celebrada en Madrid el mes de enero de 1602, donde se barajó tal posibilidad a instancias del Patriarca Ribera como único remedio eficaz para atajar la contumacia de los criptomusulmanes ${ }^{78}$.

La apuesta del dominico por una nueva campaña misional en el reino de Valencia, acompañada por el perfeccionamiento de la red parroquial existente, logró aparcar tan drástico recurso durante los años que ejerció como confesor del valido. Pero los escasos frutos obtenidos obligaron a la corona a reunir otra junta en 1607, de la que volvió a formar parte el padre Xavierre, ya titular del primer confesionario de la Monarquía. El religioso defendió otra vez una política de paz y moderación con los criptomahometanos para insistir en las bondades de la evangelización, preparada por un concilio provincial que estableciera los cauces de la instrucción y «se provean para ello sacerdotes doctos y ejemplares, porque se entiende que, por no serlo muchos de los que por lo pasado se ocuparon deste ministerio, en lugar de hacer provecho, hicieron daño». Conforme al parecer de fray Jerónimo, el rey dispuso la puesta en marcha de una enésima instrucción para la que habrían de ser reclutados los ministros de Dios más aptos y ejemplares ${ }^{79}$.

Ni aún así los resultados fueron los esperados. De nuevo, las soluciones drásticas cobraron fuerza frente a la voz contraria del todopoderoso confesor, que investido a finales de año con la púrpura cardenalicia propondría al Consejo de Estado, en su reunión del 30 de enero de 1608, otra junta de obispos valencianos encargada de organizar un último intento misional. De correr igual suerte a los anteriores, aseguraba el dominico, la justificación del extrañamiento, del que deberían excluirse niños y ancianos, resultaría mucho más sencilla. En cualquier caso, desde el punto de vista legal, ésta sólo se conseguiría mediante una causa general tramitada por el Santo Oficio, a la

76. Vincent, Bernard, y Benítez SÁNCHEZ-BlanCO, Rafael: Op. cit., p. 15. Recuérdese, aún así, que en 1601 , con motivo de la discusión suscitada en el seno de la llamada junta de los tres en torno al extrañamiento, el padre Córdoba estimó que, de ser ésta lícita en conciencia, acaso fuera menos peligroso expulsar a los moriscos nada menos que a Terranova antes que a Berbería. HALPERIN DONGHI, Tulio: Op. cit., p. 191.

77. MorTIER, Daniel Antonin: Histoire des Maitres généraux des frères Précheurs, París: Picard et Fils, 1913, vol. VI, pp. 52-121; ECHARTE, Tomás: «El cardenal fray Jerónimo Xavierre (1546-1608)», Cuadernos de Historia Jerónimo Zurita, Zaragoza, 1981, n 39-40, pp. 151-173; GALMÉS MAS, Lorenzo: El cardenal Xavierre (1543-1608), Valencia: Provincia dominicana de Aragón, 1993; y MARTínEZ PEÑAS, Leandro: Op. cit., pp. 388-396.

78. Benítez SÁnChez-Blanco, Rafael: Heroicas decisiones..., p. 369.

79. GALMÉS MAS, Lorenzo: El cardenal Xavierre..., pp. 110-111. 
que se añadirían los cargos de lesa majestad humana caso de suscitarse algún tumulto, y «con esta provanza en común se podrá hazer justicia en común» ${ }^{80}$.

El religioso volvió a salirse con la suya, aunque su fallecimiento, sobrevenido el 2 de septiembre de aquel mismo año, hizo incontenible la expulsión, con la que tocó bregar al nuevo inquilino del confesionario regio, su hermano de hábito y criatura fray Luis Aliaga, director espiritual hasta entonces del duque de Lerma ${ }^{81}$. Desde que este fraile aragonés fuera acusado por G. Marañón de «fomentar la propensión racial del pobre rey» ${ }^{82}$, ha venido encarnando la línea más dura de la orden dominicana -en las antípodas del difunto padre Xavierre y sus predecesores- agrupada en torno al privado y acérrima partidaria de una operación quirúrgica destinada a apartar para siempre a los criptomusulmanes. En este sentido, el cambio de titularidad del confesionario habría sido decisivo para su definitiva puesta en práctica.

La interpretación propuesta resultaría impecable de no constituir, por el momento, un extendido tópico aceptado por la historiografía demasiado a la ligera. Sólo un análisis en profundidad de la documentación existente sobre el tema podría verificar tales extremos y despejar la aparente contradicción de encajar a fray Luis en el partido contrario a su protector el cardenal Xavierre, a cuya sombra, tanto él como su hermano, el obispo de Albarracín y futuro arzobispo de Valencia fray Isidoro Aliaga, habían desarrollado su fulgurante carrera ${ }^{83}$. Asimismo, podría explicarse mejor que el confesor pasara a preocuparse del futuro de los niños moriscos en los meses posteriores al decreto de expulsión ${ }^{84}$. El padre Aliaga, en efecto, sostuvo excluir de la dramática resolución a los menores bautizados, todavía con posibilidades de salvarse, porque hijos eran de la Iglesia y «por la façilidad con que con la buena enseñança y doctrina se les olvidarán los herrores que sus padres les huvieren enseñado». Convenía, pues, en opinión del religioso y conforme a lo dispuesto por la corona,

80. Cit. Benítez SÁnchez-Blanco, Rafael: Heroicas decisiones ..., p. 373.

81. CANAL, Maximiliano: «El padre Luis de Aliaga y las controversias teológicas de su tiempo», Archivum Fratrum Praedicatorum, Roma, 1932, vol. X, pp. 107-157; NAVARRO LATORRE, José: «Aproximación a fray Luis de Aliaga, confesor de Felipe III e Inquisidor General de España», Estudios del Departamento de Historia Moderna, Zaragoza: Facultad de Filosofía y Letras, 1981, pp. 1-72; GARCÍA GARCÍA, Bernardo J.: «El confesor fray Luis Aliaga y la conciencia del rey», en I religiosi a corte, teologia politica e diplomazia in Antico Regime, Roma: Bulzoni Editore, 1998, pp. 159-194; y MARTínEZ PEÑAS, Leandro: Op. cit., pp. 396-430.

82. Gregorio MARAÑón: El conde-duque de Olivares, Madrid: Espasa Calpe, 1939, p. 224.

83. CAllado Estela, Emilio: «Parentesco y lazos de poder. Las relaciones del arzobispo de Valencia fray Isidoro Aliaga y su hermano fray Luis Aliaga, confesor regio e Inquisidor general», en Espacios de poder: cortes, ciudades y villas (s. XVI-XVIII), Madrid: Universidad Autónoma de Madrid, 2002, pp. 123-138.

84. También lo haría el obispo Balaguer en Orihuela, amparando a un millar de éstos cuya permanencia y cristiana educación autorizó el Consejo de Estado siempre y cuando fuesen adoptadas medidas para evitar en el futuro cualquier contacto con sus padres y familiares. VILAR, Juan B.: Orihuela, una ciudad valenciana en la Edad Moderna. Historia de la ciudad y obispado de Orihuela, Murcia: Patronato Ángel García Rogel, 1981, t. IV-vol. II, p. 147. 
«...el traer los niños de siete años abaxo a Castilla y repartirlos entre personas piadosas y christianas para que los crien y doctrinen en nuestra santa fe... pero porque si truxessen antes de saber dónde y cómo se an de repartir sería confusión, embaraço y gasto a que se podría difícilmente acudir y forçosamente abrían de padeçer mucho, pareçe que convendrá que vuestra magestad se sirva de mandar al Consejo de Estado que mire en qué districtos y lugares se abrán de repartir, ordenando a las justiçias que, con sabiduría de los perlados, traten de qué personas christianas y piadosas se encarguen dellos, ordenando a los perlados que ayuden a esto por medio de algunos religiosos que tengan buen crédito en los lugares para que persuadan a las tales personas a encargarse de la criança y enseñança de los dichos niños» ${ }^{85}$.

Resonaban las palabras de fray Luis mientras algunos frailes blanquinegros se aprestaban a legitimar el extrañamiento de los cristianos nuevos. Unos, al margen hasta entonces de la cruzada antimahometana, como el padre Francisco Diago, cronista de la Provincia dominicana de Aragón, disfrazaron su oportunismo con un acto inquebrantable de fidelidad a Felipe III, «pluguiendo a Dios los huviera echado de España desde el principio» ${ }^{86}$. Otros, que desde hacía años venían reivindicando expedientes similares como genuinos martillos de moriscos, no pudieron sino vivir el éxito como propio.

\section{MARTILLOS DE MORISCOS}

La historiografía apologética de la expulsión morisca -se ha escrito recientemente $-{ }^{87}$ tuvo su alfa y omega en la figura del dominico valenciano fray Jaime Bleda, autor del primero y último tratado justificativo de la medida, aparecidos en 1610 y 1618 , respectivamente, bajo los títulos de Defensio fidei in causa neophitorum sive morischorum regni Valentiae, totiusque Hispaniae y Corónica de los moros de España ${ }^{88}$. El compromiso del padre Bleda con esta causa se remontaría, no obstante, décadas atrás. Venido al mundo en Algemesi, cursó estudios superiores de Teología en la cercana Valencia, a decir de algunos, que según otros siguió en Salamanca ${ }^{89}$. Sin ordenarse sacerdote todavía, en 1584 obtenía de manos de don Juan de Ribera un beneficio ecle-

85. Archivo General de Simancas (AGS): Estado, Leg. 208. Ed. BorONAT Y BARRACHINA, Pascual: Op. cit., vol. II, pp. $577-578$.

86. ARCPV: Ms. 67, Memoria del maestro fray Francisco Diago, f. 126v. Sobre la vida de fray Francisco Diago y su obra, FuENTES, Celedonio: Escritores dominicos del reino de Valencia..., pp. 99-107; Garganta, José María: «Los dominicos de la Provincia de Aragón en la historia de la espiritualidad (siglos XIV-XVII)», Teología Espiritual, Valencia, 1957, vol. I, p. 93; y EsPONERA CERDÁn, Alfonso: Aproximación a la historiografía dominicana ibérica desde el Renacimiento hasta la Ilustración», Archivo Dominicano, Salamanca, 2003, vol. XXIV, pp. 120-121.

87. VINCENT, Bernard, y BENÍTEZ SÁNCHEZ-BLANCO, Rafael: Op. cit., p.24.

88. De ambas, de su contenido y autor, además de los citados en la nota anterior, han tratado durante las últimas décadas, por este orden, Tulio Halperin Donghi: Op. cit., pp. 201-202; PeSET Reig, Mariano, y HERNÁNDEZ SEMPERE, Telesforo M.: «De la justa expulsión de los moriscos de España», Estudis, Valencia, 1994, no 20, pp. 231-252; y Adolfo ROBLES SIERRA y Alfonso ESPONERA CERDÁN: «Documentos sobre la expulsión de los moriscos del reino de Valencia..., pp. 390-395.

89. FUENTES, Celedonio: Escritores dominicos del reino de Valencia ..., pp. 62 y ss. 
siástico en la parroquia de Corbera, lugar de moriscos. En su nueva condición, no tardó en presenciar las maneras acostumbradas por los cristianos nuevos, especialmente durante la celebración de la misa. Él mismo nos lo cuenta con todo lujo de detalles

«...entré en la iglesia a la hora que el vicario alçava el Santíssimo Sacramento un día de fiesta. Quedéme arrodillado junto a la puerta sin que lo advirtiessen los moriscos. Vi que aquellos infieles, en lugar de adorar la sacratíssima hostia y cáliz a la hora de la elevación, hazían todo escarnio y burla de la Sacrosanta Eucharistía: las mugeres pellizcavan las criaturas para que llorassen, ninguno avía que no hiziesse sus meneos y monerías en manifiesta irrisión, vilipendio y desacato del Santíssimo Sacramento. Quedé atónito y muy desconsolado de ver injuriado a mi Redemptor con actos tan notoriamente hereticales ${ }^{90}$.

El joven, que indignado puso su cargo a disposición del Patriarca, permaneció en aquella rectoría aún unos meses hasta mudar su vocación inicial e ingresar en el convento de Predicadores de Valencia. Allí mismo, con motivo de las cortes reunidas en 1585, tuvo ocasión de exponer a Felipe II su parecer sobre tan irreverente minoría. Al año siguiente, vestía el hábito blanquinegro y dedicaba su noviciado a traducir al latín el proceso de beatificación de su hermano fray Luis Bertrán, manejando sus escritos sobre los mahometanos. En 1590 las autoridades de la orden lo destinaban a su localidad natal, contándose entre los fundadores del convento de San Vicente Ferrer, levantado por aquellas fechas. Meses más tarde, empeñado en denunciar ante el papa la irreverencia de los infieles criptomusulmanes, marchó por primera vez a Roma con cartas de recomendación del entonces virrey, don Francisco Moncada y Folch de Cardona, marqués de Aitona, y el favor del cardenal Alejandrino, protector de los hijos de santo Domingo. Auxiliado por uno y otro, logró entrevistarse con Gregorio XIV, quien lo remitió a su penitenciario, Hippolito Aldobrandini, futuro Clemente VII. Parece que el padre Bleda intimó con el italiano, asegurando con posterioridad que «platicamos muchas vezes de mi materia morisca y lastimole mucho el desacato que estos infieles hazían al Santíssimo Sacramento en la missa» ${ }^{91}$.

De vuelta a Valencia, el arzobispo Ribera compensaba los esfuerzos del religioso con la rectoría de Sollana, donde compuso un Libro de los milagros del Santíssimo Sacramento en antipatía y opugnación de los sacrílegos blasfemos y blasfemias hereticales que los pérfidos moriscos cometían contra el Divino Sacramento, impreso en la misma capital allá por 1592, bajo el título más contenido De la archicofadría de la Minerva y milagros del Santíssimo Sacramento. A petición propia, pronto abandonó este lugar de cristianos viejos en busca de acción, ocupando durante la década siguiente diferentes parroquias de nuevos convertidos -enumeradas en páginas anteriores-para demostrar su herejía y apostasía general, desmontar los posibles argumentos de sus defensores y reclamar la expulsión como única solución. El balance de tales pesquisas nos lo ofrece su mismo autor

90. BledA, Jaime: Corónica de los moros de España..., p. 938.

91. Ibid.: p. 940. 
«Hallé que, de los catorze artículos de la fe, no creýan sino el primero de la divinidad, y esse, con tantos errores de los hereges andropomorfitas, que a la verdad no era verdadero Dios el que ellos fingían y creýan... De suerte que toda nuestra fe la derribavan por el suelo y assí eran verdaderos apóstatas de toda ella. Saqué también por muchos indicios que guardavan toda la secta infame del falso profeta. Reduxe todas las razones que hallé para hazer evidencia desta verdad a noventa y un argumentos, a los quales llamé indicios. Y por su orden los escriví en mi Defensa de la fe... $\rangle^{92}$

Después de presentar al Patriarca los primeros borradores de la citada obra, estructurada en tres tratados, fray Jaime marchó a Madrid en 1600 para hacer lo propio con Felipe III, amparado, entre otros, por el duque de Lerma y su hermano el marqués de Villamizar, así como el virrey de Valencia, don Juan Alfonso Pimentel de Herrera, conde de Benavente, a quien el religioso venía sirviendo en el confesionario. A instancias de la corona, y junto al también dominico fray Domingo Mendoza, consultor del Santo Oficio y predicador general, el padres Bleda pasó a trabajar en la creación de una cofradía en defensa de las cruces injuriadas por los enemigos de la fe en los caminos, plazas y templos del reino, sobre las que acababa de escribir Quatrocientos milagros y muchas alabanzas de la Santa Cruz. Una breve estancia en Valencia le obligó entretanto a posponer sus verdaderos desvelos editoriales hasta el año siguiente, después de haber conseguido no sin esfuerzo las censuras favorables de sus hermanos de hábito fray Andrés Balaguer y fray Jerónimo Alcocer ${ }^{93}$. De nuevo en la corte, solicitaba licencia para imprimir su libro, examinado ahora por el Consejo Real a través del jesuita Luis de la Puente, que recomendó su traducción al latín por estar prohibido, al menos en Castilla, escribir en lengua vulgar contra los herejes. Fray Jaime, con todo y con eso, no perdió el tiempo, logrando participar al rey su opinión sobre los moriscos, recurrir a la Suprema e intervenir -por indicación del valido- en la junta que sobre el tema andaba reunida en Valladolid ${ }^{94}$.

Aprovechando el nombramiento del conde de Benavente como lugarteniente general de Nápoles, el dominico viajaba con él a Italia a finales de 1602, convertido en capellán de su casa, para tratar de hacer escuchar su voz en la Santa Sede, obtener el visto bueno para la cofradía de la Santa Cruz y sacar adelante la publicación de la Defensa de la fe, vertida ya a la lengua de los Césares. En septiembre del año siguiente era recibido en Capua por el cardenal Roberto Bellarmino, animándole éste a entrevistarse con el papa Clemente VII, a quien había conocido nuestro protagonista tiempo atrás, recuérdese. Así lo hizo el religioso, sometiendo el pontífice al juicio de la Inquisición romana los asuntos que le habían llevado a la Ciudad Eterna. Confiado en el éxito de sus gestiones, tomó un barco de vuelta a la Península Ibérica a comienzos de 1604 para informar al soberano, que celebraba cortes en Valencia ${ }^{95}$.

92. Ibid.: p. 943.

93. Ibid.: p. 956.

94. Ibid.: pp. 961-962.

95. Ibid.: pp. 963-964. 
Nuevas dificultades trastocarían en breve los planes del padre Bleda. Durante su estancia romana había despachado con el vicario general dominicano, fray Luis Istela - otro discípulo bertraniano, catedrático del Estudi General valentino y superior antaño del convento de Predicadores del cap i casal $^{96}$ - para tratar de ganarle a su causa. Pero al vicario, que «se le hazían tan nuevos mis argumentos como si le hablara de la China» -como dejó anotado su interlocutor- no tomó en serio las acusaciones formuladas contra los moriscos, «mas lo tuvo por invención mía mal fundada» cual lego que era el tema, puesto que «nunca vivió entre moriscos ni los trató, ni menos los conoció; y para estar bien enterado de todos sus sacrilegios, era residir entre ellos con mucha atención $y$ de ninguna suerte bastava ser valenciano y vivir en esta ciudad de Valencia muchos años». Así las cosas, transcurridas una semanas de su regreso, el padre Istela mandó al religioso que «me recogiesse en mi convento y no saliesse de mi Provincia a tratar más con el papa ni con el rey desta causa». ${ }^{97}$. No pudo ser ajeno a esta decisión el Maestro general de la orden de Predicadores, fray Jerónimo Xavierre, que contrario a los radicales planteamientos del padre Bleda en materia de cristianos nuevos, habría utilizado a su mano derecha en el gobierno blanquinegro para acallarlo. Pese a todo, poco tiempo permaneció el reo entre los muros de Santo Domingo, socorrido por su prior fray Diego Mas, concienzudo tomista de renombre que hizo valer su ascendente sobre el marqués de Villamizar, de quien era confesor, para obtener la absolución del fraile ${ }^{98}$.

En noviembre de 1607 -con el respaldo de las dos primeras autoridades del reino de Valencia, como eran el arzobispo Ribera y el virrey don Luis Carrillo de Toledo, marqués de Caracena- volvía a Roma por la puerta grande el responsable de la Defensio fidei, pertrechado con varios manuscritos de su obra y una veintena larga de memoriales que entregó a los cardenales de la Congregación del Santo Oficio iniciado el año siguiente, con el placet de Paulo V. No logró evitarlo el padre Luis Istela, que vetó la entrada de su hermano de hábito en la Ciudad de los Papas, constituciones dominicanas en mano, para impedir que sus andanzas pudieran repercutir en la elección del nuevo Maestro general de la orden celebrada por entonces con él mismo como candidato oficial, desbancado finalmente por fray Agostino Calamini, impuesto por el pontífice $^{99}$. El padre Bleda pudo así volver a defender ante la Santa Sede sus tesis sobre

96. VidAL y Micó, Francisco: Op. cit., pp. 485-487; y RoBles, Laureano: «Profesores de la Facultad de Teología de la Universidad de Valencia (1550-1600)», en Corrientes espirituales..., pp. 100-102.

97. BledA, Jaime: Corónica de los moros de España..., p. 964.

98. FuENTES, Celedonio: Escritores dominicos del reino de Valencia ..., pp. 179-181. Más detalles sobre tan distinguido teólogo castellonense en ROBLES, Laureano: «Profesores de la Facultad de Teología...», p. 111; y FELIPO ORTS, Amparo: La Universidad de Valencia durante el siglo XVI (1499-1611), Valencia: Universitat de València, 1993, pp. 114-115. Véase también el trabajo de GALLEGO SALVADORES, Jordán: «La aparición de las primeras Metafísicas sistemáticas en la España del XVI: Diego Mas (1587), Francisco Suárez y Diego Zúñiga (1697)», Escritos del Vedat, Torrent, 1973, vol. III, pp. 91-162. Recientemente se ha editado MAS, Diego: Disputación metafisica sobre el ente y sus propiedades transcendentales (1587), Pamplona: EUNSA, 2003.

99. MORTIER, Daniel Antonin: Op. cit., vol. VI, pp. 122 y ss. 
los mahometanos, remitiéndosele a la junta de obispos reunida en la capital del Turia, adonde regresó de inmediato ${ }^{100}$.

Claro que la suerte de la comunidad morisca estaba ya echada. De ella no supo fray Jaime sino durante una nueva estancia en Madrid, coincidiendo con la publicación de la expulsión en Valencia el 22 de septiembre de 1609, furibundamente justificada desde el púlpito de la seo por otro dominico, el padre Ceferino Francisco Tomás ${ }^{101}$. Había llegado el momento de que la Defensio fidei viera la luz, con una sustanciosa ayuda de cuatrocientos ducados otorgados a finales de año por el Consejo de Aragón siguiendo instrucciones de Felipe III. En los meses siguientes, su autor completaba el original con un tratado final sobre el extrañamiento repleto de loas a sus artífices, desmesuradas en el caso del duque de Lerma, a quien dedicaría esta última parte. En mayo de 1610 la obra merecía una última aprobación de los censores que daba vía libre a su edición en las prensas valentinas de Juan Crisóstomo Garriz.

Pero el libro todavía conocería algunos problemas que amargaron la existencia de fray Jaime, no tanto en los territorios de la Monarquía, donde obtuvo una extraordinaria acogida editorial, como en el corazón de la Cristiandad. De nuevo, las disputas domésticas en la orden de Predicadores jugaron una mala pasada al religioso, en la persona esta vez del padre Damián Fonseca, un fraile lisboeta hijo del convento de Predicadores de Valencia y profesor del Estudi General, en el que había regentado una cátedra de Teología Escolástica ${ }^{102}$.

Fray Damián emprendió viaje a Roma, decretada ya la salida de los cristianos nuevos, cumpliendo órdenes de la corona para suavizar el malestar ocasionado en la Santa Sede por una medida sobre la que no había sido consultada ${ }^{103}$. Llevaría consigo cuanta documentación pudo recopilar para defender la expulsión ante Paulo V. Buena parte de los papeles seleccionados le fueron facilitados por el padre Bleda, incluido un manuscrito de su aún inédita Defensio fidei, que «buelta de arriba abaxo» acabó publicando el portugués como suya a finales de 1611, en la misma Ciudad Eterna, con el título Del giusto schacciamento de moreschi da Spagna libri sei; obra elogiada por las censuras de sus hermanos de hábito fray Giovanni Gonzale de Albelda y fray Tomasso Pallavicino, y avalada por el vicario general de la orden de Predicadores, el padre Serafino Sicco. La edición castellana del texto aparecía también en Roma, un año después, dedicada a don Francisco de Castro, embajador de Felipe III en la Santa Sede, del

100. BLEDA, Jaime: Corónica de los moros de España ..., pp. 970-974.

101. Biblioteca Nacional de España (BNE): Ms. 9.498, Sermón sobre la falsa conversión de los moriscos, predicado en la seo de Valencia, domingo a 27 septiembre de 1609, cinco días después de haberse hecho el pregón de la expulsión, ff. 30-45. De él se ocuparon ya VINCENT, Bernard, y BENÍTEZ SÁNCHEZ-BLANCO, Rafael: Op. cit., p. 15.

102. MARTÍNEZ, Francisco: Un portugués maestro e historiador valenciano. Nuevos datos para la biografia de Fonseca, Valencia: Hijo de F. Vives Mora, 1923; y RoBLES, Laureano: «Dominicos portugueses en Valencia (siglo XVI)», Arquivo Histórico Dominicano Portugués. Actas do II Encontro sobre História Dominicana, Oporto, 1986, vol. III / 2, pp. 166-175

103. BUV: Ms. 159, PRADAS, Jerónimo: Memoria de las cosas sucedidas en este convento desde el año 1603 asta el año 1628, f. 101. 
que fray Damián había comenzado a ejercer como capellán, cargo simultaneado con el de socio del nuevo maestro del Sacro Palacio pontificio, el dominico padre Istela, compensado de este modo por su derrota en el último cónclave blanquinegro ${ }^{104}$.

Los primeros ejemplares del libro vendidos en Valencia provocaron el estupor de fray Jaime Bleda, al ver impresos sus planteamientos en unas páginas con exiguas referencias a él y su obra, de la que aseguraba se habría valido el padre Fonseca para escribir de unas gentes de las que «estuvo siempre tan lexos», cuyas costumbres poco le interesaban y menos aún su lengua, que nunca aprendió ni supo entender. El religioso guardó la compostura públicamente, llegando a justificar años después el comportamiento del portugués

«...no tuve por ofensa quando ví el libro impresso que se llamasse autor dél, aunque no me nombrava ni citava por autor de cosa... No me dio pena que se hiziesse dueño y autor dello, porque entre los amigos y hermanos se puede algunas vezes no llamar señor de la cosa que possee el otro, y mejor si es su hijo, qual me professo yo deste y de todos los de mi sagrada orden, y también porque entre los religiosos todas las cosas son comunes ${ }^{105}$.

No le perdonaría, sin embargo, que desde su privilegiada posición al lado del maestro del Sacro Palacio, y al igual que éste, dejara a su suerte la Defensio fidei, víctima de un auténtico calvario en la corte pontificia al que ninguno de ambos frailes debió de coger por sorpresa. La prohibición de su distribución más allá de la frontera del Tíber precedió a la intervención de la Inquisición, motivada por las denuncias a la Santa Sede contra su contenido. Ni fray Damián Fonseca ni fray Luis Istela hicieron nada por la obra, se dolía el padre Bleda, pese a lo cual y para gozo suyo «fue hallada pura y limpia y triunfó de todos» ${ }^{106}$.

Con ánimos renovados, fray Jaime pudo dedicarse a la elaboración de una segunda composición sobre los moriscos, que anunciada en el prólogo de la primera se había demorado por las circunstancias expuestas. Publicada finalmente el año 1618, en Valencia, la algo trasnochada Corónica de los moros de España hilvanaría a lo largo de su millar de páginas una historia general de los musulmanes, o para ser más exacto de la lucha de los españoles contra los moros, a quienes aún expulsados hacía casi una década no olvidaba su autor. Como tampoco a Felipe III, en sus últimos años de vida, y al ya denostado duque de Lerma, objeto ambos de toda suerte de alabanzas como salvadores de la patria, frente a los enemigos de la fe en general, en una larga cruzada de la que las glorias dominicanas habían sido igualmente partícipes. Empezando por el patriarca de Caleruega, fundador de la orden de Predicadores nacida para servir a la Iglesia «en el ministerio de la predicación y confesión, en confutar heregías y convertir o quemar herejes o desterrallos de entre los fieles». Digno hijo de santo Domingo de Guzmán había sido también fray Tomás de Torquemada, artífice para el padre Bleda del Santo Oficio, al que debía la Monarquía Hispánica no haber sucum-

104. RoBLeS, Laureano: «Dominicos portugueses en Valencia...», pp. 172-173.

105. BledA, Jaime: Corónica de los moros de España..., p. 947.

106. Ibid.: p. 948. 
bido a las herejías que asolaban Europa. El mismo san Luis Bertrán había encabezado la vanguardia de cuantas voces críticas se escucharon contra los cristianos nuevos, alertando con su espíritu profético de los infinitos males derivados de su permanencia en la Península... ${ }^{107}$

Dejaba en el tintero fray Jaime a aquellos hermanos de hábito que, desde una posición más conciliadora, confiaron hasta el último momento en una suerte distinta para los moriscos que al final no pudo ser. Así lo quiso la corona y a ello contribuyeron otros tantos hijos de santo Domingo.

107. Ibíd.: pp. 406-407, 640-641, 890... Véase, en cualquier caso, VINCENT, Bernard, y BENíTEZ SÁNCHEZBlanCO, Rafael: Op. cit., pp. 26 y ss. 